Portland State University

PDXScholar

\title{
China and Global Imbalances from a View of Sectorial Reforms
}

Hiro Ito

Portland State University

Ulrich Volz

University of London

Follow this and additional works at: https://pdxscholar.library.pdx.edu/econ_fac

Part of the Economic Theory Commons, and the Public Economics Commons Let us know how access to this document benefits you.

Citation Details

Ito, H. and Volz, U. (2013), China and Global Imbalances from a View of Sectorial Reforms. Review of International Economics, 21: 57-71.

This Article is brought to you for free and open access. It has been accepted for inclusion in Economics Faculty Publications and Presentations by an authorized administrator of PDXScholar. Please contact us if we can make this document more accessible: pdxscholar@pdx.edu. 


\title{
China and Global Imbalances from a View of Sectorial Reforms
}

\author{
Hiro Ito and Ulrich Volz*
}

\begin{abstract}
This article examines the impact of sectorial reforms on current account imbalances, with a special focus on China. In particular, we investigate to what extent reforms pertaining to the financial sector, social protection, and healthcare may contribute to a rebalancing of China's persistent current account imbalances. Our forecasting results suggest that reforming the financial sector would be a significant contributor to the country's rebalancing with an effect much larger than that of capital account liberalization. Strengthened provisions of social protection and publicly-funded healthcare are also found to contribute to a rebalancing of the Chinese economy.
\end{abstract}

\section{Introduction}

Most economists would agree that correcting microeconomic distortions in countries with persistent current account imbalances is a central precondition for global macroeconomic rebalancing. For China, the country with the largest current account surplus, it has been frequently asserted that the country's massive current account surplus derives from microeconomic or sectorial distortions that have led to excessive saving (e.g. Lardy, 2012).

For one, it has been claimed that the lack of financial development has imposed a "financial repression tax" on Chinese households (Pettis, 2012), discouraging household consumption and thereby encouraging household saving. A lack of financial development and access to credit has also encouraged corporate saving; firms, especially small and medium-sized privately owned firms, have to rely on internal earnings as the major source of finance. Whether state-owned or private, Chinese firms tend to redistribute only a fraction of their profits in the form of dividends, which has also contributed to depressing households' disposable income and private consumption. Thus, the financial system in China has allowed corporate saving and household saving to rise hand in hand.

Underdeveloped public social safety net systems are also commonly blamed for China's excessive saving. Despite the rapid growth, China's public expenditure for social protection is insufficient given its level of economic development. China's social protection expenditure (as a share of gross domestic product (GDP)), whether or not

\footnotetext{
* Volz: Department of Economics, SOAS, University of London, Thornhaugh Street, Russell Square, London WC1H 0XG, UK. Tel: +44-207-8984721; Fax: +44-207-8984559. E-mail: uv1@soas.ac.uk. Also affiliated to German Development Institute/Deutsches Institut für Entwicklungspolitik (DIE), Tulpenfeld 6, 53113 Bonn, Germany. Ito: Department of Economics, Portland State University, 1721 SW Broadway, Portland, OR 97201, USA. Tel: +1-503-7253930; Fax:+1-503-7253945; E-mail: ito@pdx.edu. Ito thanks Portland State University for financial support. Helpful comments by two anonymous referees, Guonan Ma, Gunther Schnabl, Naoyuki Yoshino and other participants at the conference "Intra-European Imbalances, Global Imbalances, International Banking, and International Financial Stability", 17-18 September 2012, Berlin, are gratefully acknowledged. The working paper version of this article has been circulated as Asian Development Bank Institute working paper No. 393. The usual disclaimer applies.
} 
to include healthcare, is lower than the average for all developing countries. Furthermore, the coverage of social protection is still far from universal or uniform. Hence, limited coverage of or accessibility to social safety nets, public health insurance, and the public pension system have contributed to a general perception (especially in the rural areas) that people need to protect themselves from economic uncertainty by allocating a high portion of their income for a rainy day. The marketization efforts of the corporate sector after the 1990s drastically shrank the once comprehensive, "cradle-to-grave" social safety net, or "iron rice bowl," exacerbating the precautionary saving motives. ${ }^{1}$

Against this backdrop, in this article, we focus on how sectorial reforms in the financial sector, social protection, and healthcare programs are likely to affect current account imbalances as well as saving and investment. To this end, we conduct panel data analysis using a comprehensive dataset that covers 83 countries from 1995 through 2008. Using cross-country regularity found in the estimations, we then unravel China's possible peculiarities and shed light on the potentially prominent role of sectorial issues in the global imbalances debate.

\section{Estimations}

\section{Estimation Model and Data}

We first analyze the impact of the structural characteristics of the financial, social, and healthcare systems by using a simple analytical model of current account balances as well as national saving and investment based on the work of Chinn and Prasad (2003) and Chinn and Ito (2007):

$$
y_{i, t}=\alpha_{t}+X_{i, t} \mathrm{~B}+Z_{i, t} \Gamma+u_{i, t}
$$

where $y_{i, t}$ refers to three dependent variables: the current account balance, national saving, and investment, all expressed as a share of GDP. $X$ is a vector of conventional macroeconomic and policy control variables that are often used in the literature. It includes government budget balance; net foreign asset as a ratio to GDP based on the dataset created by Lane and Milesi-Ferretti (2007); private credit creation as a measure of financial deepening; the Chinn-Ito $(2006,2008)$ measure of financial openness; and a measure of legal/institutional development, which is the first principal component of law and order, bureaucratic quality, and anti-corruption measures. It also includes net foreign assets as a ratio to GDP; relative income (to the USA); its quadratic term; relative dependency ratios on young and old population; terms of trade (TOT) volatility; output growth rates; trade openness (measured as exports plus imports over GDP); and the dummies for oil exporting countries. To capture common, global shocks to the countries in our sample, we also include time fixed effects in the estimation. $^{2}$

$Z_{i, t}$ is a vector of microeconomic or sectorial variables pertaining to domestic financial reform, public expenditure on social protection, and public healthcare expenditure. The variable for domestic financial reforms is based on a dataset created by Abiad et al. (2008). While Abiad et al. use the sum of seven component indexes as the measure of financial reform (with the full extent of liberalized/reformed markets taking the value of 21), we use the sum of six component indexes by excluding the index for capital account openness, because we include the capital account openness 
index separately in our estimation. That makes the total value of the index 18. Since the index only refers to financial liberalization/deregulation efforts pertaining to domestic issues, we call the modified index the "domestic financial liberalization/ reform" index. For the sake of easy interpretation, we normalize the aggregate measure to make it range between zero and one. ${ }^{3}$

Another variable included in $Z_{i, t}$ is public social protection expenditure (such as unemployment benefits) provided by the government as a ratio to GDP. This variable is available from the International Monetary Fund (IMF) for the period 19942008. A subset of this variable refers to public social protection expenditure excluding healthcare expenditure (as a ratio to GDP). The difference between the two variables represents healthcare expenditure provided by the government (as a ratio to GDP). These three variables are available for 1995-2007 or 2008. We include another variable for public healthcare expenditure as a ratio to GDP, which is extracted from the World Bank's World Development Indicator (WDI) and available for the period 1995-2009.

Admittedly, our variables pertaining to social protection are all quantitative in nature as they show the expenditures of concerned items as ratios to GDP. Needless to say, qualitative measures of social protection policies are quite limited at best. However, our analysis focuses on developing countries (especially China), and these countries tend to lag behind advanced economies in terms of the amount of expenditure on social protection. Hence, in this analysis, we treat an increase in these variables as an "improvement in social protection," which we consider as synonymous to implementing "reforms" in the areas of social protection.

We construct panels of non-overlapping 5-year averages for all explanatory variables except for net foreign assets to GDP, TOT volatility, and trade openness. ${ }^{4}$ The data are mostly extracted from publicly available datasets such as the World Development Indicators, International Financial Statistics, and World Economic Outlook.

The original annual data include 87 countries, 23 industrial and 64 developing countries, covering the period $1995-2008 .{ }^{5}$ To estimate the determinants of current account balances, national saving, and investment, we apply the ordinary least squares (OLS) estimation model to the same set of regressors separately for the full sample, and the subsamples of industrialized countries (IDC), developing countries (LDC) and emerging market economies (EMG). ${ }^{6}$

\section{Estimation Results and Interpretations}

Tables 1-3 provide our results for the estimations on current account, national saving, and investment for the groups of developing and emerging market countries, the countries of our focus in the following empirical analysis. A complete set of estimation results, including those for IDCs, can be found in the discussion paper version of this article (Ito and Volz, 2012).

In the following, we examine the three sets of regressions collectively. Conceptually, the effects of the explanatory variables from the national saving and investment models should add up to those in the current account estimation. However, this does not have to be the case for the following two reasons. First, while the current account regressions account for the covariance of national saving and investment, simply adding two coefficients does not. ${ }^{7}$ Second, as a result of differing data conventions (balance of payments accounting vs national income accounting definition), the flows may not add up exactly. However, it is still worthwhile to compare the results from the 


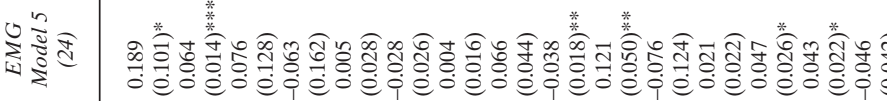

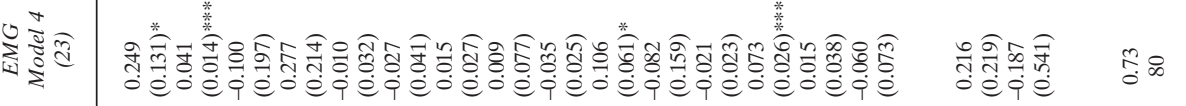
$\stackrel{20}{8}$

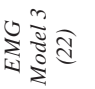

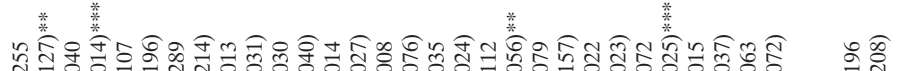

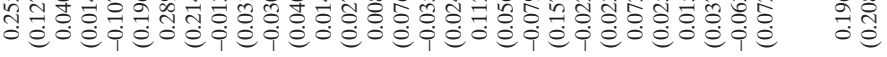

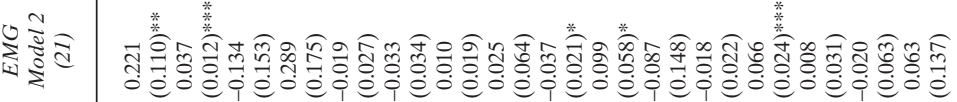

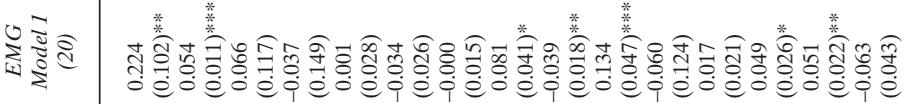

产密

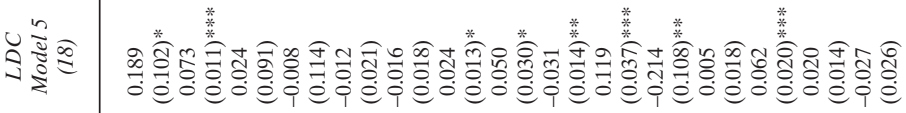

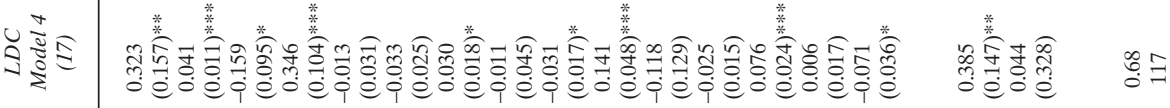

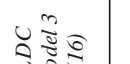

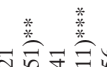

密

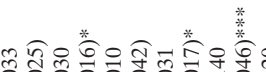

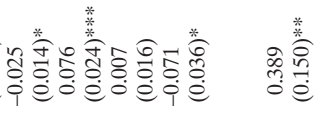

$\stackrel{80}{\circ}=$

บุป

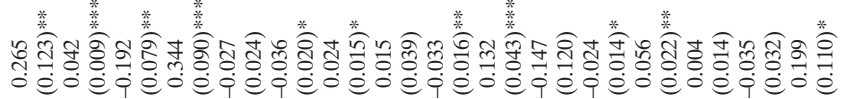

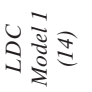

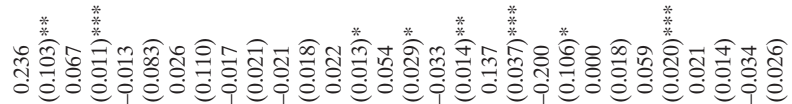

蒙

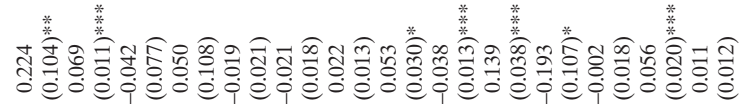




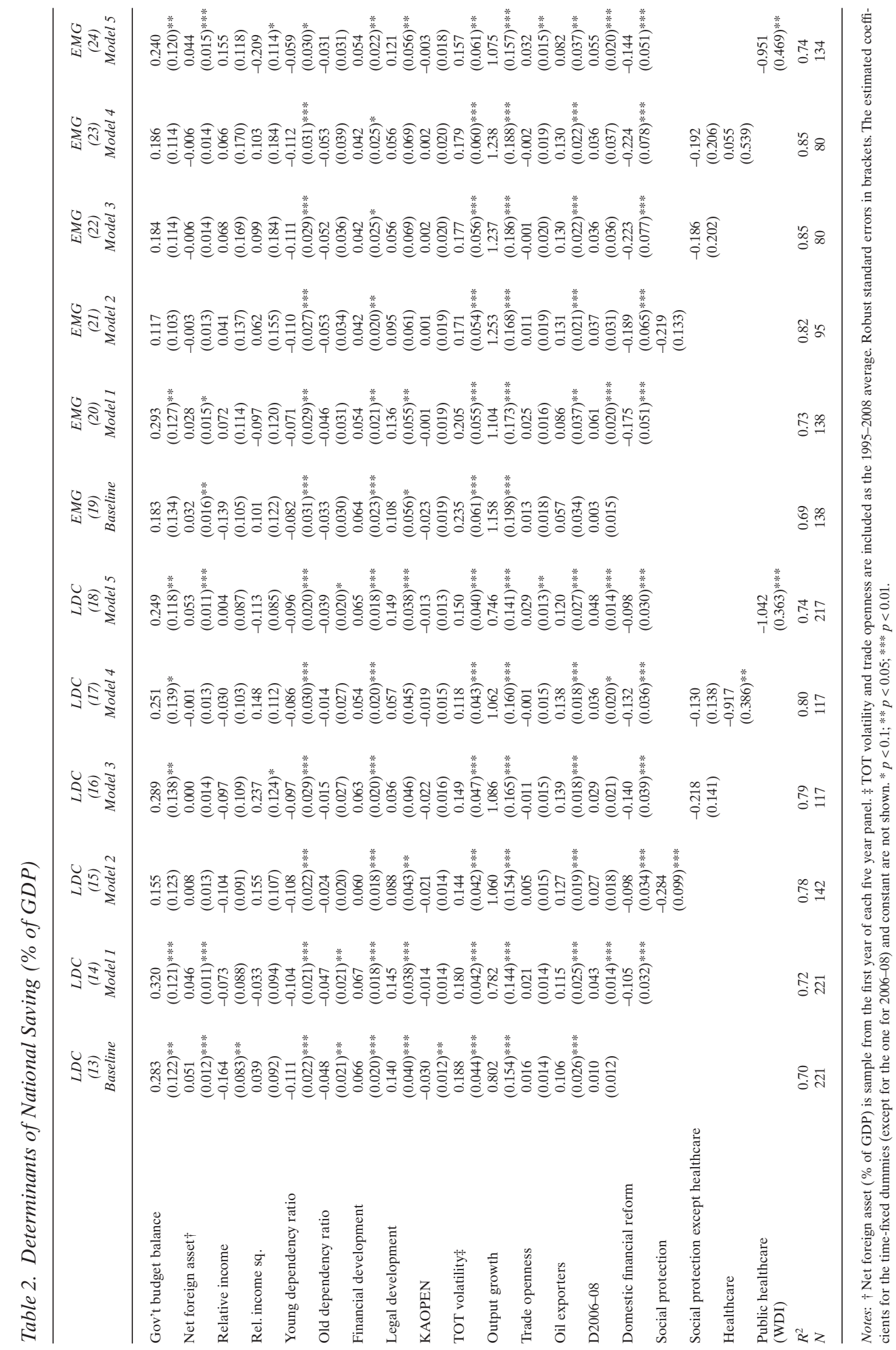




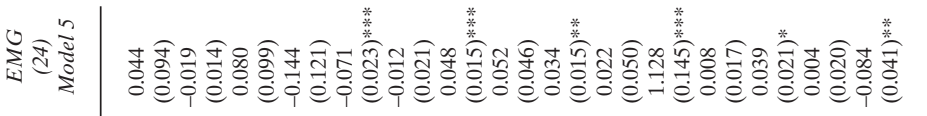

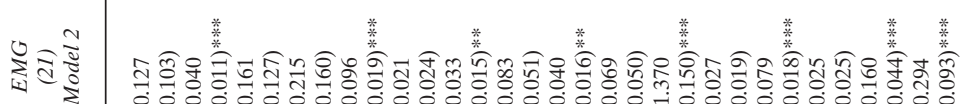
१宅

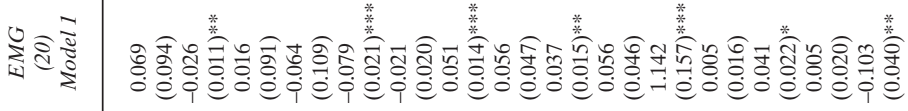

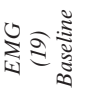

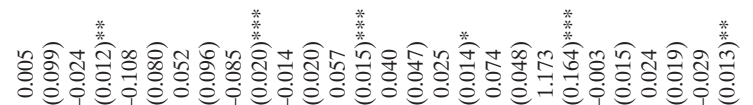

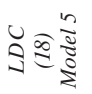

o

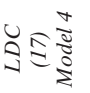

蓄

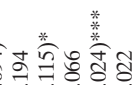

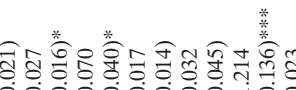

(1)

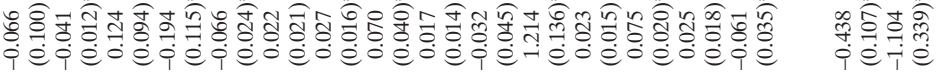

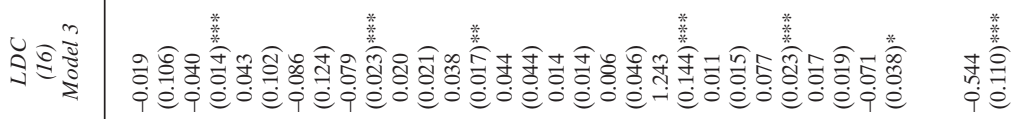

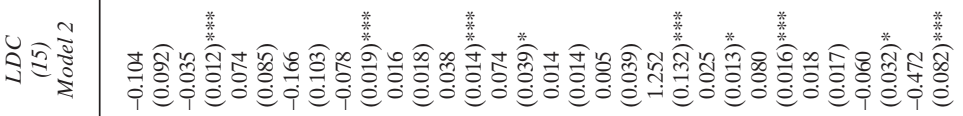

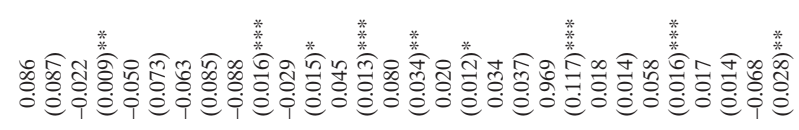

(

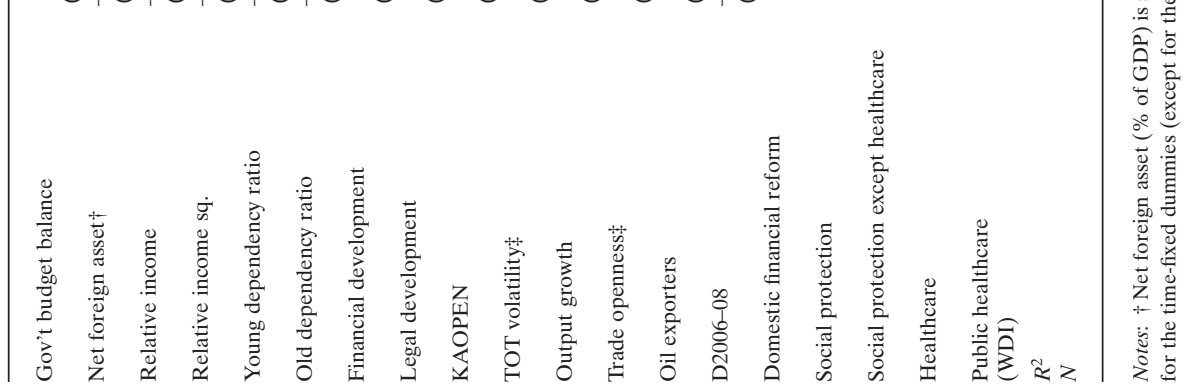


national saving and investment estimations with those in the current account estimations so that we can have some ideas about the channel through which variables can affect the current account.

Our estimates of the standard macro variables are in line with the findings of previous empirical analyses. Among the variables of our interest, we can see in Table 1 that domestic financial reform can have a negative, though only sporadically significant, impact on the current account balance among developing or emerging market economies. However, domestic financial reform is found to contribute significantly and negatively to both national saving and investment. This suggests that the weak results of the current account estimations may arise because the negative effects of domestic financial reform on both national saving and investment tend to cancel out each other.

Our estimations confirm that domestic financial reform would help reduce national saving, possibly by increasing the accessibility to financial resources and reducing the motivation for precautionary saving (Johansson and Wang, 2012). ${ }^{8}$

The negative impact of domestic financial reform on the levels of investment may be explained by its role of mitigating financial repression and correcting overinvestment. Developing countries often experience overinvestment by repressing financial markets and funneling financial resources to certain industries that are deemed strategically important through industrial policy or governmental guidance as we have observed in China now and also in several other East Asian countries in the past.

Increasing social protection expenditure, excluding healthcare, would reduce national saving for developing or emerging market countries, though the effect is not statistically significant for the latter groups of countries. For investment determination, in contrast, social protection, whether including healthcare or not, is found to contribute negatively. One explanation may be that more spending on social protection programs causes externality in the sectors that provide social protection, shifting resources from traditional, more manufacturing-oriented, investment-intensive sectors to more service-oriented and less investment-intensive sectors such as senior care and healthcare. Hence, as more social protection is being provided, more service-oriented sectors would grow, reducing the level of investment in more capital-intensive, traditional industrial sectors. The larger, negative impact of this variable on investment than that on national saving can explain the positive impact of social protection, whether or not including healthcare, on current account balances.

Healthcare expenditure is persistently found to be a negative contributor to both national saving and investment, especially for developing and emerging market countries. The results are confirmed when we use the public healthcare variable from the WDI database which covers a larger number of countries. Thus, if the public sector takes care of part of the healthcare expenditure, individuals would face less need for precautionary saving. This basically supports the mainstream policy recommendation that China should increase public safety nets and public health/pension systems to reduce national savings, which would increase domestic consumption, reduce export dependency, and contribute to rebalancing the economy.

Let us focus on three more variables, even if they are not necessarily micro-sectorial variables, since they are quite relevant to policy issues facing China. The first two variables of our interest are those pertaining to demography, namely young and old dependency ratios. Our estimation results are consistent with conventional theory such as the life-cycle income hypothesis; both young and old dependency ratios are found to have significantly negative impacts on national saving in the full sample, though it is more of the young dependency ratio that has persistent and significantly negative impacts on both national saving and investment. 
Many China observers are concerned about the potential impact of the population aging in China, which is argued to be faster than that of Japan. As far as our estimation results are concerned, a potential increase in the old population is not expected to have much impact on the current account balances, national saving, and investment. However, a drop in the young population, which is about to become a big issue for the country (Tyers and Golley, 2010), seems to contribute to lowering both national saving and investment. Yet, a drop in investment may be bigger than that in national saving, which would eventually lead to an improvement in the current account of China.

Lastly, capital account openness is found to have a negative and significant impact on current account balances especially for the subgroup of developing countries. A developing country with more open financial markets tends to become a recipient of capital. This finding is particularly relevant to China, because its financial markets are relatively closed despite the country's rapid economic growth and high degree of trade openness. For the 2006-08 period, the capital openness index (KAOPEN) scores a mere 0.16 (with the value of 1.00 being the most open) while Brazil and Russia score 0.53 and 0.41 , respectively, though it is on par with India. Despite its recent advocacy for internationalization of its currency, the biggest bottleneck of such an effort is its extremely risk-averse, gradualist approach toward external financial liberalization. Our estimation results indicate that further external financial liberalization may also help the country rebalance its current account surplus.

\section{Robustness Checks}

In this sort of exercise, one must be careful about the issue of endogeneity because the estimated coefficients can be biased and with low efficiency. The generalized method of moments (GMM) estimation, either in difference or as a system, are often suggested to deal with this issue. However, in our context, because our estimation is not based on a dynamic model and also because our use of 5-year panels (instead of annual data) helps avoid serial correlation, the GMM estimation is not appropriate. Hence, we implement a two-stage least squares estimation (2SLS) with instruments as a robustness check for the variables of our focus. ${ }^{9}$

First, we instrument the variable for domestic financial reforms with the rate of inflation, the dummy for a leftist government, the dummies for legal origins (either British, French, German, Scandinavian, or Socialist), and regional dummies. An economy with higher inflation often tries to keep its financial markets repressed so as to reduce its debt burdens while its financial policy can also be a function of the government's political orientation (e.g. its relationship with the financial sector), and its legal origins (such as the common law or continental system). With these instruments, we find that, generally, the statistical significance is consistent with those in the OLS analysis, and that the magnitude of the estimates (in absolute values) is mostly larger in the 2SLS estimation.

Second, we instrument social protection expenditure, whether with or without healthcare, and healthcare expenditure with the (log of) population size, tax revenues as a share of GDP, and the dummies for legal origins and regional areas. The size of social protection programs can be affected by the population size while it can be also affected by the size of taxable base which we proxy by the size of tax revenues. The extent of social protection may differ depending on the legal origins of countries since they can affect the views on the role of the government and welfare systems. With 
these instruments, we once again obtain estimates with similar statistical significance and greater in magnitudes compared with what we found in the OLS analysis.

These findings indicate not only that our findings on the variables of our focus are robust to the issue of endogeneity but also that the previous results may represent more conservative effects of the sectorial variables. ${ }^{10}$

\section{Implications of the Estimation Results for China}

\section{Contributions of Sectorial Variables}

Figure 1 provides some visual evidence that these sectorial factors matter for saving and investment for China. It illustrates the predictions of current account balances, national saving, and investment based on the baseline model and the five models that were presented in Tables 1-3 with different sets of variables pertaining to sectorial policies, namely, domestic financial liberalization, social protection expenditure with and without healthcare, and healthcare. ${ }^{11}$

The panels of figures show that the models with sectorial variables outperform the baseline model in their predictions for all of current account balances, national saving, and investment. Including the sectorial variables narrows the gap between the actual current account balance and the baseline prediction by $0.2 \%$ to $1.4 \%$ for the period 2006-08, though our models still underpredict the country's current account by 6.9 to

(a) Current Account

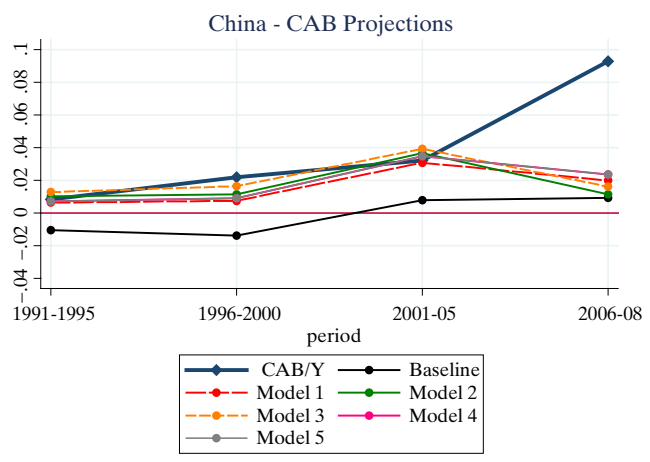

(b) National Saving

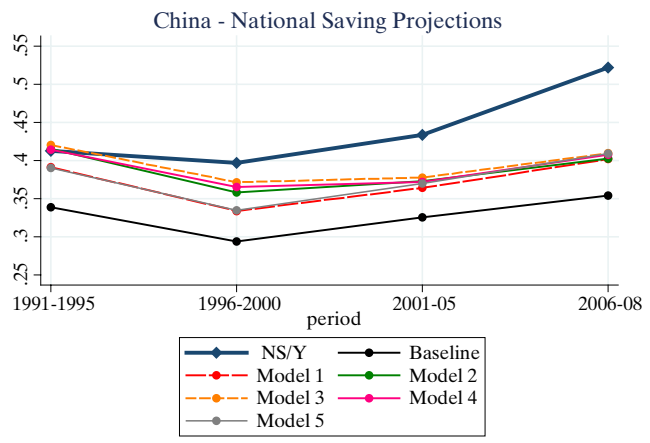

(c) Investment

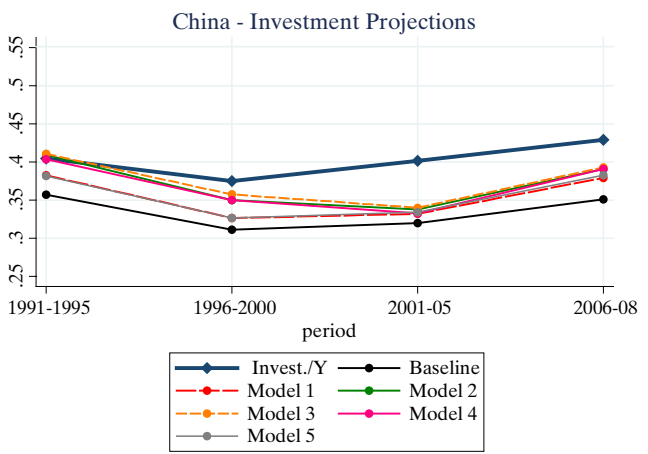

Figure 1. Projections of China's Current Account Balance, National Savings, and Investment 
(a) Current Account

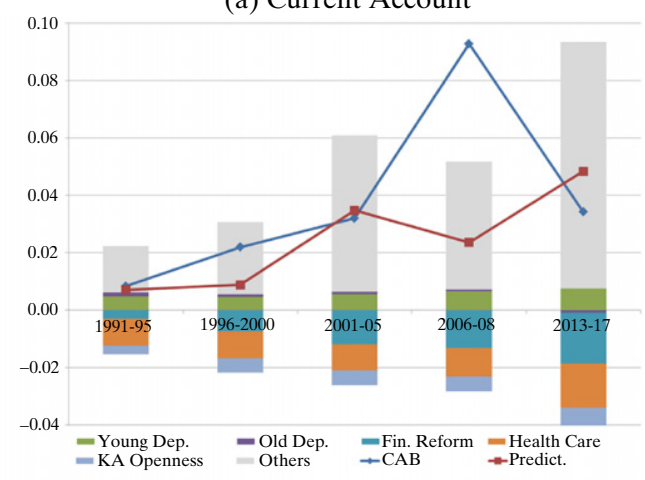

(b) National Saving

(c) Investment

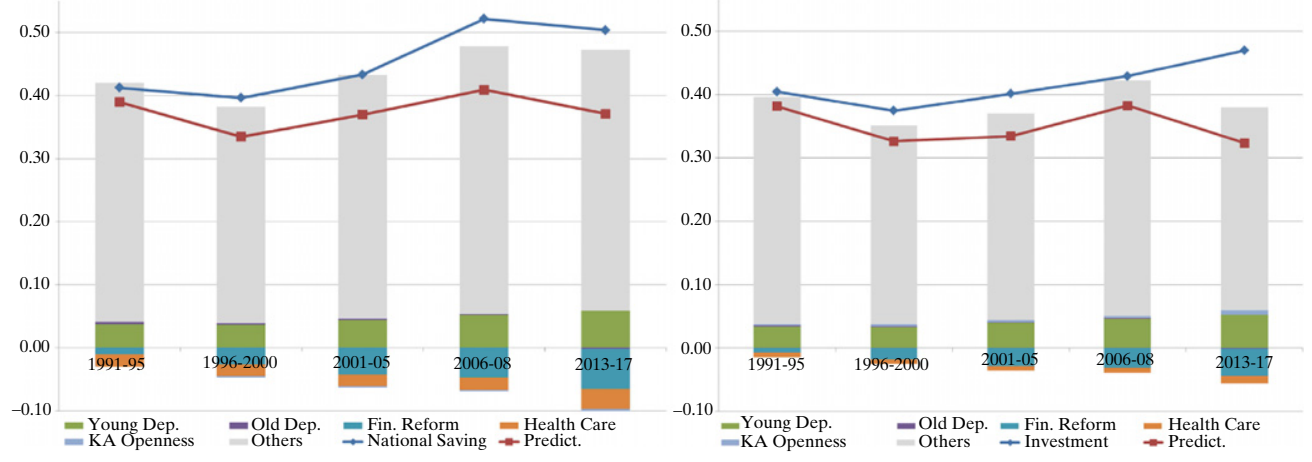

Figure 2. Contributions of the Determinants of Current Account Balance, National Savings, and Investment

8.4 percentage points. This means that other factors are contributing to the country's excessively high current account surplus in the period.

The models with sectorial variables predict national saving better than the baseline model by $4.8-5.5$ percentage points, while still underpredicting national saving in the period by 11-17 percentage points. Considering that our estimation models predict investment relatively well, we can conclude that the underprediction of China's current account balances in the period 2006-08 is mainly a reflection of the underprediction of the country's saving.

Figure 2 illustrates how the contributions of the variables of our interest to China's current account balance, national saving, and investment have evolved over time. It also shows out-of-sample predictions for the years 2013-17, based on the estimates from the regressions of Model 5 and using the assumptions describe in Table 4.

We can make several interesting observations. First, the contribution of domestic financial reform to the current account, national saving, and investment has been gradually, but steadily increasing over the years. Its contribution to China's current account is about $-1.3 \%$ in the period 2006-08, almost double compared with the period 1996-2000. The negative effect is expected to continue to rise to $-1.8 \%$ in the period 2013-17. ${ }^{12}$

Second, although its contribution is not as big as that of domestic financial reform, capital account openness also contributes to lowering the current account. As of the 2000 s, the size of its contribution is as small as $-0.5 \%$, but given that there is still much 
Table 4. Assumptions for Out-of-sample Forecasting of China's Current Account, National Saving, and Investment

Variables Assumptions

Government budget balance

Net foreign assets (initial)

Relative income

Youth and Old dependency ratios

Financial Development

Legal development

Financial openness (KAOPEN)

TOT volatility

Average GDP growth

Trade openness
World Economic Outlook projections (WEO, April 2012) are used

Assumed to be 0.35 (0.24 as of 2010)

WEO (April 2012)

Forecasts from the UN World Population Prospects Database are used

The average of the variable during the $2001-08$ period is used

Assumed to be 0.65 , higher than the $2006-08$ period's value of 0.51

Assumed to be 0.35 , higher than the sample period's average of 0.16

Same as 2006-08

WEO (April 2012)

Same as the sample period average

room for China to implement liberalization policy toward cross-border capital flows, such a policy can lower the current account surplus.

Third, the healthcare expenditure is another persistent negative contributor to the current account with the size of about $-1 \%$, suggesting that its negative contribution can rise if the Chinese government decided to increase its public healthcare expenditure.

Fourth, young dependency ratios have contributed positively to the country's current account surplus until the period 2006-08. However, if the young population changes as the United Nations projects, its contribution will stabilize (at $0.7 \%$ ) in the period 2013-17.

Fifth, similar observations can be made for national saving except for the impact of capital account openness. For the investment determination, however, young dependency ratios and domestic financial reform are bigger contributors among the variables of our focus.

Last, the sum of the contributions of the variables of our interest to China's current account, namely, young and old dependency ratios; domestic financial reform; healthcare expenditure; and capital account openness is $-2.1 \%$ in $2006-08$ and is expected to be $-3.8 \%$ in $2013-17$. The comparable figures for national saving and investment are $-1.6 \%$ and $1.1 \%$, respectively, for $2006-08$ and $-4.3 \%$ and $0.3 \%$ in $2013-17$. These figures are economically significant.

\section{Scenario Analysis-Forecasts of China's Current Account, National Saving, and Investment}

How could these reform factors contribute to future rebalancing? To answer this question, we conduct scenario analyses. More specifically, we forecast China's current account balances, national saving, and investment for the period 2013-17, conditional upon different scenarios for the sectorial development of our concern. 

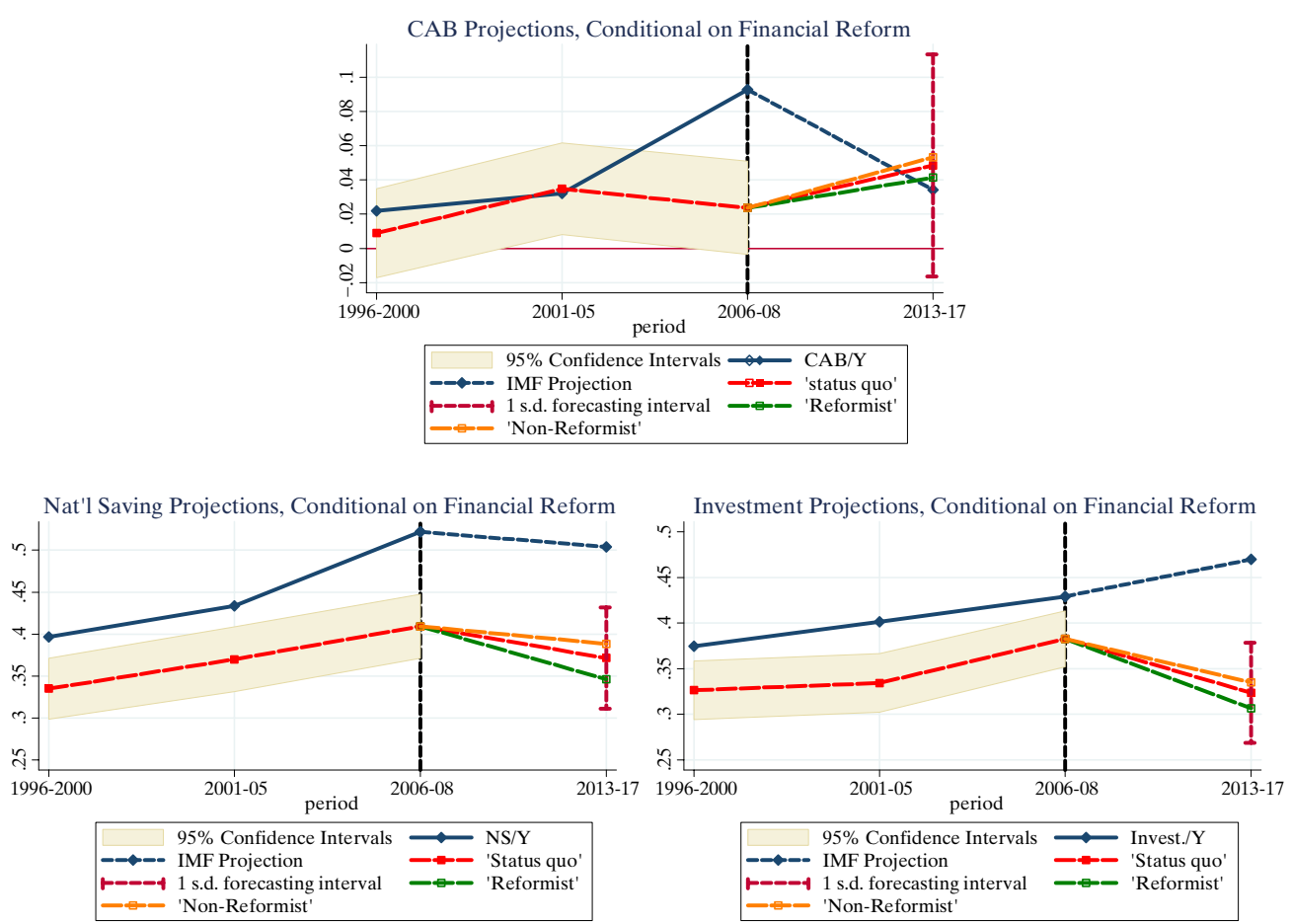

Figure 3. Projections of Current Account Balance, National Savings, and Investment, Conditional upon Domestic Financial Reform

We first examine how the forecasts of current account balance, national saving, and investment change depend on the extent of progress in domestic financial reform. Except for the variable for domestic financial reform, we again use the assumptions described in Table 4. As for the domestic financial reform variable, the baseline prediction is based on the assumption that the level of domestic financial reform will continue to increase its level with the annual trend. That is, the value of the domestic financial reform index rises from 0.48 in the period 2006-08 to 0.63 in the period 2013-17, that is the level above the 2006-08 level of domestic financial reform of Brazil. $^{13}$

We also have two "reformist" and "non-reformist" scenarios. In the reformist scenario, we assume that China will implement drastic domestic financial reform in the near future, so that the index for domestic financial reform will rise up to 0.91 , the level Argentina enjoys as of 2006-08. In the non-reformist scenario China does not proceed with domestic financial liberalization, in which case the index remains at 0.48 , a level much lower than in many other emerging economies. Figure 3 displays the results of predictions for the different scenarios. In the reformist scenario, where China implemented a drastic domestic financial reform, the current account balance would be lower than that in the baseline projection by 0.7 percentage points and lower than that in the non-reformist scenario by 1.2 percentage points. This decline seems to be due to a deterioration of national saving. The national saving rate in the reformist scenario would be lower than that of the baseline by 2.5 percentage points while the investment rate in the reformist scenario would be lower than that of the baseline by 1.7 percentage points. 
We repeat the same exercise, but look into the impact of different extents of capital account liberalization. ${ }^{14}$ In the baseline scenario, we assume the index of capital account openness rises to 0.35 in $2013-17$ from 0.16 in 2006-08. Considering that policy makers in Beijing often are known for their preference for a gradualist approach, the assumed increase appears to be reasonable. In the reformist scenario, China implements a drastic capital account opening, raising the KAOPEN index to 0.55 , about the same as Brazil's 2006-08 level of financial openness. In the nonreformist scenario, we assume that China makes no strives at capital account liberalization compared with the period 2006-08, i.e. it maintains the value of 0.16 for its KAOPEN.

The impacts of capital account liberalization on the current account balances, national saving, and investment are minimal (figures not displayed). In all scenarios, the impact on the three macroeconomic variables is less than 50 basis points above or below the baseline projection. These findings suggest that only large-scale capital account liberalization would affect China's current account balances.

Lastly, we examine the effect of reforming healthcare expenditures. In the baseline scenario, we assume that China increases the level of its healthcare expenditure as a ratio to GDP marginally to $3 \%$, a little above the level as of the period 2006-08 (i.e. about $2 \%$ of GDP). In the reformist scenario, China raises its healthcare expenditure to $4.5 \%$ of GDP, higher than the level of Brazil's but below that of Argentina as of 2006-08. In the non-reformist scenario, the healthcare expenditure drops to $1.5 \%$ of GDP. This scenario is not implausible if China experiences a high GDP growth which is accompanied by a less comparable rise in the healthcare expenditure. Our estimates suggest that China's current account surplus would fall by 0.8 percentage points in the reformist scenario (figures not displayed). The current account would worsen mainly through a fall in the level of national saving because investment is barely affected in the different scenarios. As in the case of domestic financial liberalization, improving public healthcare provisions could contribute to rebalancing China's current account surplus.

\section{Concluding Remarks}

In this article we investigated the impact of reforms in the financial sector, social protection, and healthcare on saving and investment patterns and the current account. Our findings confirmed the often expressed view that domestic financial reform would help reduce national savings rates. It would also lower the levels of investment, presumably by curtailing overinvestment resulting from financial repressive policies such as directed lending. We also found that increasing social protection expenditure, excluding healthcare, would reduce national saving for developing and emerging market countries, though the effect is not statistically significant for the latter group. Increases in social security spending can also have a negative effect on investment, possibly shifting resources from traditional, more manufacturingoriented, investment-intensive sectors to more service-oriented and less investmentintensive sectors, such as senior care and healthcare.

For China, the largest current account surplus country, our findings are particularly important. We found that the contribution of domestic financial reform to the correction of imbalances has been gradually, but steadily, increasing over the years. Moreover, although its contribution is not as big as that of domestic financial reform, capital account liberalization also contributes to a lowering of China's current account surplus. Last but not least, we find healthcare expenditure to be another persistent 
negative contributor to the Chinese current account. Based on these results, our scenario analyses provide insightful predictions on China's potential rebalancing. Our predictions suggest that domestic financial liberalization would indeed contribute to a rebalancing China's current account surplus. Moreover, China's current account surplus would decline significantly if the country increased its healthcare expenditure to a level comparable with that of Brazil, another fast-growing emerging economy, mainly by reducing the level of national savings.

Our analysis highlights the impact of microeconomic reforms on macroeconomic imbalances. In particular, it provides support for the often expressed view that financial sector reform as well as a strengthening of China's social security system would help the country to reduce national saving and thereby rebalance its macroeconomy.

\section{References}

Abiad, Abdul, Enrica Detragiache and Thierry Tressel, "A New Database of Financial Reforms," IMF working paper 08/266, Washington, DC (2008).

Chinn, Menzie D. and Hiro Ito, "What Matters for Financial Development? Capital Controls, Institutions, and Interactions," Journal of Development Economics 81 (2006):163-92.

—, "Current Account Balances, Financial Development and Institutions: Assaying the World 'Savings Glut,'” Journal of International Money and Finance 26 (2007):546-69.

_, "A New Measure of Financial Openness," Journal of Comparative Policy Analysis 10 (2008):309-22.

Chinn, Menzie D. and Eswar S. Prasad, "Medium-term Determinants of Current Accounts in Industrial and Developing Countries: An Empirical Exploration," Journal of International Economics 59 (2003):47-76.

Dooley, Michael, Jeffrey Frankel and Don Mathieson, "International Capital Mobility in Developing Countries vs. Industrialized Countries: What Do Saving-Investment Correlations Tell Us?" IMF Staff Papers 34 (1987):503-30.

Feldstein, Martin and Charles Y. Horioka, "Domestic Saving and International Capital Flows," Economic Journal 90 (1980):314-29.

Horioka, Charles Y. and Ting Yin, "Household Savings Rates and Social Benefit Ratios: Country Comparisons," in Masahiro Kawai and Gloria O. Pasadilla (eds), Effects of Social Policy on Domestic Demand, Tokyo: ADB Institute (2010):63-75.

Ito, Hiro and Ulrich Volz, "The People's Republic of China and Global Imbalances from a View of Sectorial Reforms," ADBI working paper 393, ADB Institute, Tokyo (2012).

Johansson, Anders C. and Xun Wang, "Financial Repression and External Imbalances," CERC working paper 20, Stockholm School of Economics (2012).

Lane, Philip R. and Gian Maria Milesi-Ferretti, "The External Wealth of Nations Mark II: Revised and Extended Estimates of Foreign Assets and Liabilities, 1970-2004," Journal of International Economics 73 (2007):223-50.

Lardy, Nicholas R., Sustaining China's Economic Growth after the Global Financial Crisis, Washington, DC: Peterson Institute for International Economics (2012).

Loayza, Norman, Klaus Schmidt-Hebbel and Luis Servén, "What Drives Private Saving across the World?" Review of Economics and Statistics 82 (2000):165-81.

Pettis, Michael, "China Needs a New Growth Model, Not a Stimulus," Financial Times, 14 March 2012, p. 9.

Tyers, Rod and Jane Golley, "China's Growth to 2030: The Roles of Demographic Change and Financial Reform," Review of Development Economics 14 (2010):592-610.

\section{Notes}

1. The working paper version of this article (Ito and Volz, 2012) comprehensively reviews the microeconomic distortions of China such as lack of financial development and inadequacy of public expenditure on social protection and healthcare. 
2. For the theoretical rationales for the variables that are conventionally tested as the determinants of current account, national saving, and investment, refer to Chinn and Ito (2007).

3. We update the original data, that are available up to 2005 , to 2008 by linearly extrapolating the index of "domestic" financial liberalization. If the extrapolated value goes beyond the value of 1 , it is set equal to 1 .

4. To avoid bidirectional causality, the net foreign asset data are sampled from the first year of each 5-year panel. TOT volatility and trade openness, both of which tend to be of structural nature and vary little over time, are included as the 1970-2008 average. The use of nonoverlapping five-year panels (i) mitigates the effect of measurement errors in annual data that can be particularly problematic in data for developing countries; (ii) allows us to focus our interest in medium-term rather than business cycle variations in current account balances; and (iii) helps mitigate (but not completely remove) feed-back effects between the right- and lefthand sides of the estimation equation.

5. There are four 5-year panels, starting in 1991-95. However, as a result of data limitations and possible noise from the crisis years, the last panel is composed of only 3 years, 2006-08, which we consider to be the years of the global imbalances.

6. The EMGs are defined as the countries classified as either emerging or frontier during the period of 1980-97 by the International Financial Corporation plus Hong Kong and Singapore.

7. If some change in one variable affects national saving and investment independently, as long as the change in national saving and investment does not affect each other, the net effect of the change $(\Delta N S-\Delta I)$ would be the same as that on current account balances. However, if national saving and investment are highly correlated, as has been found in many studies such as Feldstein and Horioka (1980) and Dooley et al. (1987), simply adding two coefficients does not yield the coefficient in the current account regression.

8. The finding that financial liberalization, which would usually result in higher (real) interest rates for investors, would lower the saving rate may seem counterintuitive. However, the income effect of a higher interest rate could dominate the substitution effect, leading to a lower volume of saving if the higher interest rate could help the agent to meet the same level of financial needs. Furthermore, correcting financial repression would lower the (real) interest rate for borrowers so that the need for precautionary saving could decline if an agent finds it easier to borrow from financial markets when a financial emergency arises. Loayza et al. (2000) and Horioka and Yin (2010) find a negative effect of financial sector development on the savings rate.

9. The results of the 2SLS estimations are available from the authors upon request.

10. As another set of robustness checks, we also examine whether other factors contribute to the saving and investment determination, such as the extent of urbanization, the sex ratios, and the size of service sector in the economy. For the estimation results and their discussions, refer to Ito and Volz (2012).

11. Predictions are made using the estimation results for the subsample of developing countries, i.e. columns 13-18 in each of Tables 1-3.

12. We assume the level of domestic financial reform continues to rise with the annual trend.

13. The healthcare expenditure is assumed to be $3 \%$ of GDP in 2013-17, slightly higher than the average of the period 2006-08.

14. The domestic financial reform variable is set to remain the same as in the previous baseline case, i.e. 0.63 . 